\title{
Using Combination of Zeolite, Activated Carbon and Clay in Exhausted Pipe to Reduce the Effect of $\mathrm{CO}$ and $\mathrm{NO}_{2}$ to Environment
}

\author{
Hari Rudijanto IW ${ }^{1}$, Suparmin ${ }^{2}$, Zaeni Budiono ${ }^{3}$, Budi Triyantoro ${ }^{4}$ \\ 1, 2, 3,4 Environmental Health Department, Poltekkes Kemenkes Semarang, Indonesia \\ *Corresponding Author: Hari Rudijanto IW, Environmental Health Department, Poltekkes Kemenkes \\ Semarang, Indonesia
}

Received : July 02, 2017

Accepted: July 05, 2017

Published: July 07, 2017

\begin{abstract}
Introduction: Generator set is one pollutant sources releasing the exhausted emissions of SO, NO, CO, HC, and particulate dust. The concentrations of $\mathrm{CO}$ and NO2 are taken for granted as air pollution parameters. The binding capacity of $\mathrm{CO}$ to $\mathrm{Hb}$ is tremendous at 240 times compared to $\mathrm{CO}$ binding to $\mathrm{O} 2$ that the effect to the health must be greatly observed. The utilization of activated charcoal, zeolite, and clay as adsorbent materials of $\mathrm{CO}$ and $\mathrm{NO} 2$ were analyzed to reduce the concentration of both gases as released by a generator set.
\end{abstract}

Methods: Type of research is pre-experimental with pre-test design and post-test group design. The object analyzed is the amount of airflow containing $\mathrm{CO}$ and NO2 passing through the absorber tube with activated charcoal media, zeolite and clay with different length $(1 \mathrm{~cm}, 5 \mathrm{~cm}, 10 \mathrm{~cm}, 15 \mathrm{~cm})$. The Kruskal-Wallis test is used to analyze the difference output of each adsorbent.

Results: Activated charcoal and zeolite, the combination of activated charcoal - zeolite and clay - zeolite can be used to lower the CO levels. The Kruskal-Wallis test showed that there was a significant difference between the length of the adsorbent tube, the use of a single adsorbent and the combination of the CO gas reduction

Conclusion: It is necessary for further research to modify of the adsorbent apparatus so that the pollutant of the gas molecule is diffused evenly by enlarging the diameter of the outer tube that the volume of the adsorbent media is larger.

Keywords: Activated carbon, zeolite, clay, $\mathrm{CO}, \mathrm{NO} 2$

\section{INTRODUCTION}

Electricity is one of energy sources needed for human survival leading to people efforts on how to create energy sources. Power cutoff is usually overcome with alternative technologies such as generators. Utilization of generators as an alternative electricity in the community is common although only used by certain people or offices (Septian Dwi Pramono, 2015) Smoke is a hot gas on fire. It contains a combination of gas, steam, solid well-dispersed particles. The density and toxicity of the smoke produced depend on the fuel being burned. In some cases, the smoke becomes hot and contains toxic products such as CO gas. (Diana Agusta, 2012). The bonding power of $\mathrm{CO}$ to $\mathrm{Hb}$ (blood) is immense at 240 times compared to the binding capacity of $\mathrm{CO}$ to $\mathrm{O} 2$ causing its effects to health must be properly considered. Convulsions due to nerve impairment can be caused by high $\mathrm{NO}_{2}$ gas concentrations and may also result in paralysis if the poisoning continues (Tugaswati, Tri, 2007)

Coconut shell charcoal can be used as an adsorption medium because it is not toxic, easy to obtain, economical, and efficient. Zeolite is a crystalline aluminum silica compound with a three-dimensional open frame structure composed of a cluster of tetrahedral aluminate and silicates bonding each other through oxygen atoms whose the framework of its crystal structure is in the form of a cavity and a regular 
tunnel that is not soluble in water (Gottardi, 1976). Oxygen as an oxidant is obtained from ion generators that produce plasma cluster ions in the form of $\mathrm{H}+$ and $\mathrm{O}_{2}$ ions. Clays and clay minerals are soils that have certain mineral particles that produce plastic properties on the soil when mixed with water (Grim, 1968).

\section{MATERIALS AND METHODS}

The research approach is pre-experimental with pre-test and post test group design. The objects of analysis are some gross airflow generated by the burning of fuel oil (generator set).The sample taken is some dirty air flow through the adsorbent tube with different sizes. The independent variables are the length of adsorbent, minute, type of adsorbent and the dependent variables include $\mathrm{CO}_{2}$ and $\mathrm{NO}_{2}$ emission level produced by a generator set.

The preparation stage is the manufacture of porous media containing $90 \mathrm{~g}$ of carbon. Carbon was mixed with glue solution to create a dough. The mixture was molded in a cube form with a length of $1 \mathrm{~cm}, 1 \mathrm{~cm}$ wide and $1 \mathrm{~cm}$ high. This cube was left for one night then heated in an $110^{\circ} \mathrm{C}$ oven for 3 hours. After the media had been removed from the oven, it was stored in an airtight container. Such media can be used for gas sampling (Budi Setiawan, et.al, 2007). This adsorbent media has outer and inner tube length of $20 \mathrm{~cm}$, outer tube diameter of $6 \mathrm{~cm}$ and tube diameter in $2 \mathrm{~cm}$.

Measurement of $\mathrm{CO}$ and $\mathrm{NO}_{2}$ gas content with various variations of the medium of adsorbent media $(1 \mathrm{~cm}, 5 \mathrm{~cm}, 10 \mathrm{~cm}$ and $15 \mathrm{~cm})$ aims to find the biggest reduction of gas content. Initial sampling was performed using an adsorption tube containing glass wool but without an adsorbent medium in six times replication. Sampling of $\mathrm{CO}_{2}$ and $\mathrm{NO}_{2}$ emissions (treatment) was replicated six times each on single adsorption tube (active charcoal, zeolite and clay), active charcoal and zeolite combination, activated charcoal and clay as well as zeolite and clay (moist conditions) in the molded cube $(1 \mathrm{~cm} \times 1 \mathrm{~cm} \times 1 \mathrm{~cm})$ attached to the adsorbent tube. Each combination uses a new adsorbent medium and an adsorbent tube (3 pieces) each to ensure the same (homogeneous) opportunity. Data were analyzed with KruskalWallis test

\section{RESULTS AND DISCUSSIONS}

This research is intended to observe the performance of active charcoal, zeolite, and clay in absorber tube as adsorbents of $\mathrm{CO}$ and $\mathrm{NO}_{2}$ and monitor the performance of generator set machine in the combustion process. The experimental results using the stand alone media and when combined are shown in the following tables.

Table1. Results of Gas Level Measurements $(15 \mathrm{~cm}$ long adsorbent length) with a single medium

\begin{tabular}{|l|l|l|l|l|l|l|}
\hline No. & Parameters & Units & \multicolumn{4}{|c|}{$\begin{array}{c}\text { Measurement result at } 60^{\text {th }} \\
\text { minutes }\end{array}$} \\
\hline & & & $\begin{array}{c}\text { Media } \\
1\end{array}$ & $\begin{array}{l}\text { Media 2 } \\
\text { Media } \\
3\end{array}$ & Control \\
\hline 1 & Ammonia & $\mathrm{ppm}$ & 0 & 0 & 0 & 0 \\
\hline 2 & $\begin{array}{l}\text { Carbon } \\
\text { Monoxide }\end{array}$ & $\mathrm{ppb}$ & 0 & 101010 & 0 & 101010 \\
\hline 3 & $\begin{array}{l}\text { Nitrogen } \\
\text { Dioxide }\end{array}$ & $\mathrm{ppb}$ & 44 & 44 & 44 & 44 \\
\hline 4 & Humidity & $\%$ & 72 & 72 & 75 & 73 \\
\hline 5 & Temperature & ${ }^{\circ} \mathrm{C}$ & 26 & 26 & 26 & 26 \\
\hline 6 & $\begin{array}{l}\text { Outlet } \\
\text { Temperature }\end{array}$ & ${ }^{\circ} \mathrm{C}$ & 26 & 26 & 26 & 25 \\
\hline 7 & $\begin{array}{l}\text { Speed of } \\
\text { Outlet Airflow }\end{array}$ & & 0.2 & 0.2 & 0.2 & 0.2 \\
\hline
\end{tabular}

Notes: Media 1: Active charcoal, Media 2: Cay, Media 3: Zolites, Control: glass wool

Note taking: Every15 minutes after device warming up. Adsorbent Media in humid condition and speed of generator set airflow is lowered.

Table2. Results of Gas Level Measurements $(15 \mathrm{~cm}$ long adsorbent length) with the combined medium

\begin{tabular}{|l|l|l|l|l|l|l|}
\hline No. & Parameters & Units & \multicolumn{4}{|c|}{$\begin{array}{c}\text { Measurement result at } 60^{\text {th }} \\
\text { minutes }\end{array}$} \\
\hline & & & $\begin{array}{c}\text { Media } \\
1\end{array}$ & $\begin{array}{c}\text { Media } \\
2\end{array}$ & Media 3 & Control \\
\hline 1 & Ammonia & $\mathrm{ppm}$ & 0 & 0 & 0 & 0 \\
\hline 2 & $\begin{array}{l}\text { Carbon } \\
\text { Monoxide }\end{array}$ & $\mathrm{ppb}$ & 0 & 0 & 101010 & 101010 \\
\hline 3 & $\begin{array}{l}\text { Nitrogen } \\
\text { Dioxide }\end{array}$ & $\mathrm{ppb}$ & 44 & 44 & 44 & 44 \\
\hline 4 & Humidity & $\%$ & 70 & 65 & 74 & 73 \\
\hline 5 & Temperature & $\circ \mathrm{C}$ & 26 & 28 & 25 & 26 \\
\hline 6 & $\begin{array}{l}\text { Outlet } \\
\text { Temperature }\end{array}$ & ${ }^{\circ} \mathrm{C}$ & 25 & 25 & 25 & 25 \\
\hline 7 & $\begin{array}{l}\text { Speed of } \\
\text { Outlet } \\
\text { Airflow }\end{array}$ & 0.2 & 0.2 & 0.2 & 0.2 \\
\hline
\end{tabular}

Notes: Media1: Ative charcoal + Zolites, Media 2: Cay + Zolites, Media 3: Cay + Active charcoal, Control: glass wool

Note taking: Every15 minutes after device warming up. Adsorbent Media in humid condition and speed of generator set airflow is lowered.

Researchers analyzed that media 1 (activated charcoal) and 3 (zeolite) could decrease $\mathrm{CO}$ 
concentration of $0 \mathrm{ppb}$ while in medium 2 (clay) and control (glass wool) were $101010 \mathrm{ppb}$. In decreasing $\mathrm{NO}_{2}$ gas all media and control still remain at $44 \mathrm{ppb}$. Dropping in CO gas levels occurred at minutes of 60 according to the measurement results with the criteria that the adsorbent media was in humid conditions and the airflow rate of the outlet was minimized $(0.2$ $\mathrm{m} / \mathrm{s}$ ). This finding is consistent with the adsorption theory stating that adsorption is highly dependent on the surface area of the adsorbent, the larger the adsorbent surface, the greater the adsorption power, and the greater the efficiency of the adsorption (Reynold, 1982). The results of sampling showed a decrease in $\mathrm{CO}$ and $\mathrm{NO}_{2}$ gas concentrations. This condition is due to coconut shell charcoal carbon with a more open pore character capable of absorbing $\mathrm{CO}$ gas molecules. In the gas adsorption process by the coconut shell charcoal medium shows that the smaller the gas flow rate containing the contaminant, the gas residence time in the absorber tube will be longer so that the higher the efficiency level. Coconut shell charcoal has a broad and hollow surface with a layered structure. This structure causes coconut shell charcoal to absorb gas or other substances in solution and air (Tjokrokusumo, 1995). The sampling of the generator is operated on the rotation of the stationary machine, and the measured gas flow rate is $0.2 \mathrm{~m} / \mathrm{s}$ making the $\mathrm{CO}$ concentration reduction efficiency is more optimal.

Zeolite is a crystalline silica-alumina compound with a three-dimensional open structure composed of tetrahedral aluminate (AlO4) ${ }^{5-}$ and silicate $(\mathrm{SiO} 4)^{4-} \quad$ groups which are bonded together through oxygen atoms. The active side causes the zeolite to have the ability to exchange ion, adsorbent, and catalyst (Dwyer, 1984). In control (glass wool), airflow passes only through elastic free fibers made from raw fibers and although as a good heat insulator, but $\mathrm{CO}$ and $\mathrm{NO} 2$ gases do not contract with the airway insulation fibers and silencers. In other cases, all media, 1 (activated charcoal), 2 (clay), 3 (zeolite) and control (glass wool), had no effect on the decreasing of $\mathrm{NO}_{2}$ gas content.

In media combination, the reduction of $\mathrm{CO}$ gas to the numbers from $0 \mathrm{ppb}$ occur in medium 1 (activated charcoal - zeolite), and medium 2 (clay-zeolite) whereas on the medium 3 (clayactivated charcoal) and control (glass wool) was $101010 \mathrm{ppb}$. For decreasing of $\mathrm{NO}_{2}$ gas on media 1,2,3 and control remain at $44 \mathrm{ppb}$. $\mathrm{CO}$ gas can be adsorbed because it has a size smaller than the scale of the active charcoal pore. According to Maria Qibthiyah study (2012), activated carbon has a pore diameter size of $25,39 \AA \mathrm{A}$ or $2.539 \mathrm{~nm}$, which is in line with the theory that the molecules can be adsorbed are molecules with a diameter equal to or smaller than the pore diameter of the adsorbent. This occurence is due to the contact area between the activated carbon and the smoke particles of generator increase that the possibility of activated carbon particles that collide and coagulate with smoke particles are more and more. The powder or granular activated carbon has a large surface area per unit weight because of the substantial number of fine pores (micropores) found there. This condition causes the activated carbon to absorb gas, liquid or other soluble substances (Program Studi Teknik Lingkungan ITB, 1990).

The clay consists of tiny grains $(<0.002 \mathrm{~mm})$ and shows the properties of plasticity with high porosity cohesion. The combination with zeolites that have the ability of ion exchangers, adsorbents and catalysts play a more optimal role in lowering CO gas levels. The decrease of $\mathrm{CO}$ gas content with medium 3 (clay + activated charcoal) is $101010 \mathrm{ppb}$. The researchers analyzed that both powder-shaped adsorbents when they were combined into one then would mask the pores so that the flow of $\mathrm{CO}$ gas passes only in the absence of contraction with the adsorbent medium. The $\mathrm{NO}_{2}$ gas content is likely as large as a molecular size of Nitrogen so that the adsorbate retained on the solid surface is clogged and the adsorbent reaches a saturated point. The gas contaminant passing through the adsorption zone usually has a zero concentration, but due to balanced and kinetic factors, some low concentration of gas contaminant will move in the effluent. The top of the adsorbent becomes saturated by the adsorbate and the adsorption zone shifts to the bottom. Finally, the bottom edge of the adsorption zone touches the bottom of the column, and the effluent concentration begins to rise (saturated). The time at which the adsorption zone reaches the bottom of the column and the effluent concentration starts to grow is referred to as saturation time. The adsorbent capacity in the column gets saturated with time (Kris, et.al 2008).

Other factors play roles in the adsorption process is a kind of adsorbate, adsorbent 
characteristics, adsorbate type, adsorbate pressure, adsorbate temperature, and air velocity (Khairunisa 2008). Kruskal -Wallis test showed that asymptotic significance value for the length of the adsorbent for $\mathrm{CO}$ gas is $0.000(<0.05)$, indicating the rejection of Ho. This means that there is a significant difference between the use of the length of the absorber tube and the reduction of $\mathrm{CO}$ gas in the generator. The asymptotic significance value for $\mathrm{NO}_{2}$ gas is 1.000 (> 0.05) indicating the acceptance of Ho. This means there is no significant difference between using the length of the absorber tube and the reduction of $\mathrm{NO}_{2}$ gas in the generator. The use of time-minute shows the value of asymptotic significance value for $\mathrm{CO}$ gas = 0.433 and 1.000 for $\mathrm{NO}_{2}$ which is above 0.05 indicating the acceptance of Ho. This means there is no significant difference between the use of a minute and the decreasing of $\mathrm{CO}$ and $\mathrm{NO}_{2}$ gas in the generator. In using the single media, the asymptotic significance value for the $\mathrm{CO}$ gas is $0.000(<0.05)$, indicating the rejection of Ho. This means there is a significant difference between the use of adsorbent media (single) and the reduction of $\mathrm{CO}$ gas in the generator. In using combined medium, the asymptotic significance value for $\mathrm{CO}$ gas is $0.025(<0.05)$, indicating the rejection of Ho meaning that there are significant differences between the adsorbent media use (combined) and the reduction of $\mathrm{CO}$ gas in the generator. The asymptotic significance value for $\mathrm{NO}_{2}$ gas is $1.000(>0.05)$, indicating the acceptance of Ho meaning that there is no difference exhibited significantly between adsorbent media use (combined) and the reduction of $\mathrm{NO}_{2}$ gas in the generator.

Calculation of $\mathrm{CO}$ and $\mathrm{NO} 2$ gas concentration if converted to ppm, \% and $\mu \mathrm{g} / \mathrm{m} 3$ is as follows:

$\mathrm{CO}=101010 \mathrm{ppb}=101.01 \mathrm{ppm}=0.010101 \%=$ $124.6 \mu \mathrm{g} / \mathrm{m}^{3}$.

$\mathrm{NO}_{2}=44 \mathrm{ppb}=0,044 \mathrm{ppm}=0.0044 \%=0.0891$ $\mu \mathrm{g} / \mathrm{m}^{3}$.

$\mathrm{Xppm}=\mathrm{Xppb}, \mathrm{X}(\%)=\mathrm{X}(\mathrm{ppm})$

$$
1000 \quad 10,000
$$

When calculated, the two polluting gas is relatively small. The threshold value according to Indonesian Government Regulation No. 41 of
1999 on Air Pollution Control, for 1 hour CO time measurement, the parameters is $30,000 \mu \mathrm{g} /$ $\mathrm{m} 3, \quad \mathrm{NO}_{2}=400 \mu \mathrm{g} / \mathrm{m} 3$ indicating that research results are still below national book value. However, $\mathrm{CO}$ and $\mathrm{NO}_{2}$ gases are harmful to human health.

\section{Conclusions}

The researchers concluded that activated charcoal adsorbent and zeolite were able to reduce $\mathrm{CO}$ gas. The adsorbent length is $15 \mathrm{~cm}$ as an adsorbent gas molecule in the adsorption process. Combination media of active charcoal adsorbent - zeolite and clay zeolite can be used to decrease the parameters of $\mathrm{CO}$ gas. The adsorbents of activated charcoal, zeolite, clay and their combinations have not been able to decrease for NO2 gas parameters yet. The Kruskal-Wallis test showed that there was a significant difference between the length of the absorber tube $(0.000<0.05)$, the use of a single adsorbent $(0.000<0.05)$ and a combination $(0.025$ $<0.05)$ in the $\mathrm{CO}$ gas reduction.

The researcher's suggestion is that it is necessary to modify the absorber apparatus so that the pollutant gas molecule can diffuse evenly. The outer and inner tube diameter of the absorber needs to be enlarged from the one in research so that the volume of the adsorbent medium is greater. It is worth further research to be conducted on a more dense gas which diffuses more slowly than a less dense gas at the same temperature.

\section{REFERENCES}

[1] Septian Dwi Pramono, Mengenal Arti Genset dan Manfaat Genset Dalam Kehidupan Universitas Muhammadiyah Yogyakarta, 2015

[2] Tugaswati, Tri, 2007, Emisi Gas Buang Kendaraan Bermotor Dan Dampaknya Terhadap Kesehatan, www.kpbb.org/ makalah_ ind/Emisi_Kesehatan.pdf,

[3] Gottardi, E., 1976, Mineralogy and Cristal Chemistry of Zeolites, A Selection of Paper Presented in 76 An International Conference on the Occurrence, Properties, and Utilization of Natural Zeolites, Arizona.

[4] Grim, R. E. 1968. Clay Mineralogy. $2^{\text {nd }}$ Edition. Mc Graw Hill Book Co. New York

[5] Reynold, T. D, 1982, Unit Operations, And Processes In Environmental Engineering. Brooks, Cole Engineering Division Monterey: California. 
[6] Dwyer, 1984, Zeolite Structure, Composition and Catalysis, Chemistry and Industry, April ed., 258-264.

[7] Marisatul Qibthiyah, , 2012, Uji Performa TiO2 Karbon Aktif Berbahan Dasar Tempurung Kelapa Sawit Sebagai Adorben Gas CO Dari Asap Kebakaran, Skripsi Fakultas Teknik UI, Jakarta

[8] Cheremisinoft, 1998, Carbon Adsorption Hand Book, Ann Arboor. Science : New Jersey.

[9] Tjokrokusumo, 1995, Pengantar Enjiniring Lingkungan, Sekolah Tinggi Teknik Lingkungan "YLH"”, Yogyakarta

[10] Program Studi Teknik Lingkungan ITB, 1990, Pengantar Pecemaran Udara, Institut Teknologi Bandung

[11] Khairunisa, Ratana, 2008, Skripsi : Kombinasi Teknik Elektrolisis dan Teknik Adsorpsi
Menggunakan Karbon Aktif Untuk Menurunkan Konsentrasi Senyawa Fenol Dalam Air, Depok : Universitas Indonesia.

[12] Kris Tri Basuki, Budi Setiawan, Nurimaniwathy, 2008, Penurunan Konsentrasi $\mathrm{CO}$ Dan $\mathrm{NO}_{2}$ Pada Emisi Gas Buang Menggunakan Arang Tempurung Kelapa Yang Disisipi $\mathrm{TiO}_{2}$, Seminar Nasional IV SDM Teknologi Nuklir Yogyakarta.

[13] Budi Setiawan, \& Rosyidin, Nurimaniwathy, 2007, Reduksi Warna dan BOD Limbah Tekstil Menggunakan Karbon - $\mathrm{TiO}_{2}$, BATAN Yogyakarta.

[14] Diana Agusta, 2012, Skripsi Uji Gas CO Pada Asap Kebakaran Dengan Menggunakan Karbon Aktif Dari Arang Tempurung Kelapa Yang Terimpregnasi $\mathrm{TiO}_{2}$, Fakultas Teknik Universitas Indonesia.

Citation: Hari Rudijanto IW, Suparmin, Zaeni Budiono \& Budi Triyantoro, Using Combination of Zeolite, Activated Carbon and Clay in Exhausted Pipe to Reduce the Effect of CO and NO2 to Environment.ARC Journal of Public Health and Community Medicine. 2017; 2(2):24-28doi:dx.doi.org/10.20431/24560596.0202004

Copyright: (C) 2017 Authors. This is an open-access article distributed under the terms of the Creative Commons Attribution License, which permits unrestricted use, distribution, and reproduction in any medium, provided the original author and source are credited. 